have been described in the article. The most popular ones are as follows: "CI International Day", "Chinese New Year / Spring" and "Chinese bridge". Perspectives of the research are seen in the further study of the tactical and strategical means enabling the development of students' scientific potential within the International project "Confucius Institute".

Keywords: professional speech training, translators / interpreters of Chinese, extra-class activity, Confucius Institute, professional competence, educational and cultural events, university education.

Подано до редакиії 10.10.2016

Рецензент: д. пед. н., проф. І. В. Бужина

UDC: 371.134 / 378.22 / 811.58

Nataliia Oskina,

PhD (Candidate of Pedagogical Sciences), associate professor, Department of Western and Eastern Languages and Methods of their Teaching, South Ukrainian National Pedagogical University named after K. D. Ushynsky, 34, Staroportofrankivska Str., Odesa, Ukraine

\title{
PROFESSIONAL TRAINING OF A BACHELOR OF ORIENTAL STUDIES AT A PEDAGOGICAL UNIVERSITY
}

The paper deals with the concept of "professional training of a bachelor of Oriental studies at a pedagogical university". This training is seen as a process of formation of professional-pedagogical competence of bachelors of Oriental studies. In turn, the designated competence is seen in the ability of individuals to resolve complex specialised tasks and practical problems in teaching a certain oriental discipline successfully, taking into account the various socioculturally conditioned patterns of behavior, activities and development of the societies of the Asian-African space area in the context of global cultural interaction.

Keywords: professional training, Oriental studies, Orientalist, bachelor, professional-pedagogical competence.

At the time when political, economic and cultural relations of Ukraine in the international arena are rapidly expanding, long-term development of relations between Ukraine and Oriental nations encouraged the emergence of scientific interest in the East. Research in that direction necessitates the formation of professional training: of specialists-philologists-orientalists (teachers and translators) of the Persian, Arabic, Japanese, Chinese, Korean, Turkish languages, Hindi; specialists in international affairs, political scientists with deep knowledge and fluency in foreign languages for the purpose of conferment of a qualification of an interpreter; diplomats-specialists in the following areas: international relations (studies), management of foreign economic activity; orientalistsculturologists, country studiers and historians.

Teachers training for future activities has been the subject of research of many scientists (O. Abdullina, L. Ahmedzyanova, I. Bogdanova, F. Honobolin, I. Zyazyun, E. Karpova, N. Kichuk, L. Kondrashova, N. Kuzmina, S. Kurlyand, A. Lynenko, G. Nagorna, V. Slastonin, L. Spirin, E. Ulyatovska, R. Hmelyuk, O. Tsokur et al.).

Trying to specify a research state of professional pedagogical training of bachelors of Oriental studies at a pedagogical university, a review of contemporary psychological and educational research on this issue has been conducted.

The works of G. Balabanov, M. Bastun, A. Goncharenko are devoted to research prospects of
Oriental studies in Ukraine, to the issue of formation of humanistic mind oriented towards individual dialogical relations of a specialist-orientalist.

Psycho-pedagogical aspects of future philologistsorientalists training were studied by G. Tsereteli, I. Brahinskyy, N. Pyhulevska, Asmoyil Hakim, Gita Tadzhrabekori, Muhammad Kozym Kahdavi, A. Buyanova, T. Halmyrzaeva, B. Mukhamedzhanova, Z. Umarov, S. Bahny. Ways of formation of motivation to learning in the process of future specialists becoming were investigated by Imam Karoi Mukadum, Mansoor Fahim, Mazhhon Mohram.

M. Arslan, O. Asadchiy, K. Dovbnya, V. Poroshina, L. Zhurba, A. Vernyhora, A. Nestorova, W. Zheng, L. Sokratova studied linguistic and methodological aspects of the acquisition of professional knowledge by future specialists-orientalists.

It should be noted that the specifics of professional training of bachelors of Oriental studies at a pedagogical university was neglected by these scientists. That allows us to actualise the study of this problem.

The purpose of the article is to explore and to define the concept of professional training of bachelors of Oriental studies at a pedagogical university.

The training of future specialists-orientalists is performed in classical and pedagogical universities, specialised language institutes, research centers, special courses in different faculties at universities. 
In V. Fedina's study, development of Oriental studies in Ukraine is associated with the opening of secondary schools, oriental faculties, institutes of higher education that train specialists in Oriental studies. Since the 80s of the last century, specialists-orientalists training has been restored in Ukraine at Ivan Franko National University of Lviv, Lviv Polytechnic National University, Kyiv National Linguistic University, Taras Shevchenko National University of Kyiv, Kiev Institute of Social and Cultural Relations, Kyiv University "Eastern World", National University of "Kyiv-Mohyla Academy", Kramatorsk Economic and Humanitarian Institute, Taras Shevchenko National University of Luhansk, Oles Honchar Dnipropetrovsk National University, Taurida National V. I. Vernadsky University (Simferopol), Institute of Oriental studies and International Relations "Kharkiv Collegium", Averroes Ukrainian-Arab Institute of International Relations and Linguistics, and others [12].

Before we define the concept of professionalpedagogical training in general and turn to training of bachelors of Oriental studies at a pedagogical university, it is necessary to determine the concept of "Orientalism" and "a bachelor of Oriental studies", because it is the understanding of these concepts in current conditions that will determine the nature of training in our study.

Large Collegiate Dictionary defines Orientalism as a complex of sciences, exploring the history, language, literature, philosophy, art, monuments of spiritual and material culture, economy and socio-political order in Asia and South Africa, as well as the peoples of eastern origin in Eastern and Central Europe [2]. You can also come across the term "Orientalism", which comes from the Latin word "orientalis" - eastern and denotes the set of disciplines that study the history, economics, language, literature and art of the East [6].

Definition of "an Orientalist" is given through the definition of "Oriental studies", "Orientalism": Orientalist is a specialist in Oriental studies [10].

Oriental studies are traditionally divided into two areas: Classical East research and Contemporary East research. The experts-representatives of these areas can be defined accordingly. Classical East experts are those who study eastern civilisations of ancient and medieval era, and also the traditional intrinsic elements that still retain its vitality. Contemporary East Experts explore modern Afro-Asian countries, study transformational effects of colonialism and the progress of the national liberation movements in the territory of the East, the role of the eastern states in global and regional processes today, their literature and art [5].

But we find the definition of Oriental studies suggested by Ye. Zelenyev and V. Kasevich the most convincing, namely, Oriental studies is an integrating interdisciplinary science that seeks to learn as much as a wide range of a variety of artificial forms and socially conditioned behavior models, creativity and levels of societies development of predominantly Asian-African space area, considering their socio-cultural existence in the context of the scientific paradigm of global interaction of cultures and civilisations [5].

According to our research, we also need to specify the concept of "a bachelor of Oriental studies". The first (bachelor's) level of higher education corresponds to the sixth qualification level of National Qualifications Framework and provides a person's acquisition of theoretical knowledge and practical skills, sufficient to perform professional duties successfully in the chosen specialty [4].

In other words, the person who is awarded a bachelor's degree demonstrates the ability to solve complex problems and specialised practical problems in a particular sphere of professional activities or in the learning process, which involves the use of certain theories and methods of a relevant science and is characterised by complexity and uncertainty of conditions [8].

Therefore we consider a bachelor of Oriental studies as a graduate who demonstrates the ability to solve complex specialised tasks and practical problems related to the study of a wide variety of artificial shapes and socially conditioned behavioral patterns, creativity and levels of development of societies of predominantly Asian-African space area, considering their socio-cultural existence in the context of the scientific paradigm of global interaction of cultures and civilisations.

A bachelor's diploma specifies a qualification consisting of information about a degree of higher education, specialisation, and in some cases - professional qualifications [4]. This qualification is the result of the assessment and recognition that is received when the authorised institution has established that a person has achieved competencies (learning outcomes) in accordance with the standards of higher education, as certified by the relevant document on higher education [4].

All this information is reflected in the educational qualification characteristics of specialties. We considered the example of the Faculty of Foreign Languages of South Ukrainian National Pedagogical University named after K. D. Ushynsky, which provides training for bachelor's degree, particularly in the specialty "014 Secondary Education. Language and Literature (Chinese)", "014 Secondary Education. Language and Literature (Turkish)". Accordingly, the qualifications of a teacher of the Chinese / Turkish languages are specified in diplomas.

As you can see, the specificity of a pedagogical educational institution requires focusing on the fact that its graduates-bachelors are educators and teachers and their training is a priori targeted at it. This fact obliges us to make appropriate adjustments in our understanding of a bachelor of Oriental studies.

So, a bachelor of Oriental studies is a specialist who was qualified as a teacher of a specific discipline (particular oriental language), and who shows in his/her work the ability to solve complex specialised tasks and practical problems of teaching certain disciplines, taking into account the diversity of artificial forms and socially conditioned behavior, creativity and levels of development of 
societies of predominantly Asian-African space area in the context of the scientific paradigm of global interaction of cultures and civilisations.

The fact that we have identified a bachelor of Oriental studies as a specialist who was qualified as a teacher of a certain discipline, allows us to consider this professional training through the prism of competence, because qualification is an official result of assessment and recognition of the fact that a person has achieved competencies (learning outcomes) according to the given standards [4].

Theoretical study of methodological and pedagogical literature allowed us to make this assumption. We believe that professional-pedagogical competence as a result of professional training will characterise training of bachelors of Oriental studies at a pedagogical university most fully and thoroughly. Let us give our opinion on this matter.

$\mathrm{Yu}$. Solyanykov conducted a theoretical study that made it possible to determine general characteristics of the research on competence. In his study, the concept of "competence" in humanitarian theories is seen as a person's ability to deal with everyday problems based on his/her self-efficacy (A. Bandura and W. Michel); a specific power based on achievement motivation necessary for effective implementation of specific actions in a particular subject area (J. Raven); a characteristics of a qualification that presents the knowledge necessary for the realisation of a professional activities (G. Serikov); total capacity based on the knowledge, experience, values, aptitudes acquired through training (B. Calney, S. Shishov) [11].

Yu. Solyanikov singled out the following viewpoints essential for the mentioned approaches: "competence" is an activity category, i.e. it is manifested only in certain activities; competence is not limited to knowledge or skills, but contains them in itself; a significant role in the manifestation of a competence is played by a particular situation, in the same field but in different circumstances a person can either show or not show this competence; to demonstrate a competence the assigned tasks, the individual interest in solving problems are significant; education is an essential factor in the development of competence [11].

J. Raven defined competence as a specific ability required for effective implementation of specific actions in a particular subject area, which includes highly specialised knowledge, a special kind of substantive skills, ways of thinking and understanding of responsibility for the actions. To be competent means to have a set of specific competences of different levels [9].

According to M. Kholodnaya [13], competence is a special type of subject-specific knowledge that allows making effective decisions in the relevant field of activities. In her opinion, the knowledge should meet the following requirements: diversity, structuring, flexibility,

\section{ЛІТЕРАТУРА}

1. Бодалев А. А. Вершина в развитии взрослого человека / А. А. Бодалев. - М. : Флинта, Наука, 1998. efficiency and accessibility, applicability in new situations, categorical nature [13].

Professional competence, as noted by T. Brazhe [3], is determined by holistic orientations of a specialist, by motives of his/her activities, by his/her awareness of him-/herself in the world and the world around him/her, by the style of interacting with people, by common culture, by the ability to develop his/her own creative potential [3]. To the mentioned above O. Bodalev adds initiative, organisational skills, the ability to assess the impact of one's activities; he considers it the highest level of competence [1].

N. Kuzmina describes pedagogical competence as "a set of skills of a teacher as a subject of pedagogical influence in a special way to construct scientific and practical knowledge" in order to deal with the educational problems more efficiently [7]. The main indicator of pedagogical competence is considered by the author as the level of teacher's acquisition of structural, organisational and operational functions of the educational process.

V. Fedina in her work determines professional competence of future specialists-orientalists as integral system formation that provides the quality of their professional activities, and is composed of socio-cultural and professional knowledge and individual personality traits; cognitive skills, value-orientation, transformative and communicative activities; motivation to professional readiness, professional ability and professional orientation [12].

All of the previously mentioned allows us to accept the opinion of many fellow scientists who consider that professional-pedagogical competence as a result of professional training characterises bachelors of Oriental studies at a pedagogical university most fully and thoroughly.

Law of Ukraine "On Higher Education" provides laconic and meaningful definition of competence as a dynamic combination of knowledge, skills and practical skills, ways of thinking, professional, philosophical and civic qualities, moral and ethical values that define the person's ability to carry out professional and further training activities successfully and are the result of training at some level of higher education [4].

Having taken this understanding of competence as a basis and considering previous conclusions, we note that, in our opinion, professional training of a bachelor of Oriental studies at a pedagogical university is the process of formation of professional-pedagogical competence, which determines the ability of individuals to solve complex specialised tasks and practical problems successfully in teaching a certain oriental discipline, taking into account the diversity of forms of artificial and socially conditioned behavior, creativity and levels of development of societies of predominantly Asian-African space area in the context of the scientific paradigm of global interaction of cultures and civilisations.

2. Большой энциклопедический словарь [Електронний ресурс]. - Режим доступу : http://www.vedu.ru/bigencdic/12213/. 
3. Браже Т. Г. Развитие творческого потенциала учителя / Т. Г. Браже // Советская педагогика. - 1989. - №8. - С. 89-94.

4. Закон України «Про вищу освіту» №1556-VII від 01.07.2014 [Електронний ресурс]. - Режим доступу : http://zakon2.rada.gov.ua/laws/show/1556-18.

5. Зеленев Е. И., Касевич В. Б. Введение в востоковедение. Общий курс / Е. И. Зеленев, В. Б. Касевич. Санкт-Петербург : КАРО, 2010. - 570 с.

6. Комлев Н. Г. Словарь иностранных слов [Електронний ресурс] / Н. Г. Комлев. - 2006. - Режим доступу http://dic.academic.ru/dic.nsf/dic_fwords/24806.

7. Кузьмина Н. В. Профессионализм личности преподавателя и мастера производственного обучения / Н. В. Кузьмина. - М. : Высшая школа, 1990. - 119 с.

8. Постанова Кабінету міністрів України «Про затвердження Національної рамки кваліфікацій» № 1341 від 23.11.2011 [Електронний ресурс]. - Режим доступу : http://zakon2.rada.gov.ua/laws/show/13412011.

\section{REFERENCES}

1. Bodalev, A. A. (1998). Vershyna $v$ razvytyy vzrosloho cheloveka [The top in adult human development]. Moscow: Flinta-Nauka [in Russian].

2. Bolshoy entsyklopedicheskiy slovar [Large encyclopedic dictionary]. (n.d.). Retrieved from: http://www.vedu.ru/bigencdic/12213/ [in Russian]

3. Brazhe, T. H. (1989). Razvitie tvorcheskogo potentsiala uchitelya [Development of creative potential of a teacher]. Sovetskaya pedagogika - Soviet pedagogy, 8, 8994 [in Russian].

4. Zakon Ukrayiny "Pro vyshchu osvitu”. [The law of Ukraine “On Higher Education”]. (n.d.). za-

kon2.rada.gov.ua. Retrieved from:

http://zakon2.rada.gov.ua/laws/show/1556-18 [in Ukrainian].

5. Zelenev, Ye. Yu., \& Kasevich V. B. (2010). Vvedeniye $v$ vostokovedeniye. Obschiy kurs [Introduction to Oriental Studies. General Course]. St. Petersburg: KARO [in Russian].

6. Komlev, N. H. (2006). Slovar inostrannykh slov [Foreign words dictionary]. Retrieved from:

http://dic.academic.ru/dic.nsf/dic_fwords/24806 [in Russian].

7. Kuzmina, N. V. (1990). Professionalizm lichnosti prepodavatelya $i$ mastera proizvodstvennogo obucheniya [Professionalism of personalities of a teacher and a master of vocational learning]. Moscow: Vysshaya shkola [in Russian].

8. Postanova Kabinetu ministriv Ukrainy "Pro zatverdzhennia Natsionalnoi ramky kvalifikatsii” "[The Cabinet of
9. Равен Д. Компетентность в современном обществе. Выявление, развитие и реализация / Д. Равен. - М. : «Когито-Центр», 2002. - 400 с.

10. Словник української мови: в 11 томах [Електронний ресурс]. - Т. 9. - 1978. - С. 898. - Режим доступу : http://sum.in.ua/p/9/898/1.

11. Соляников Ю. В. Обеспечение качества подготовки магистрантов педагогического университета к научно-исследовательской деятельности : дис... канд. пед. наук: 13.00.08 / Юрий Владимирович Соляников. Санкт-Петербург, 2003. - 169 c.

12. Федина В. С. Формування професійної компетентності у майбутніх фахівців-сходознавців: автореф. на здоб. наук. ступеня канд. пед. наук : спец. 13.00.04 «Теорія і методика професійної освіти» / В. С. Федина. - Київ, 2009. - 22 с.

13. Холодная М. А. Психология интеллекта. Парадоксы исследования [Серия «Мастера психологии»] / М. А. Холодная. - СПб : Питер, 2002. $-272 \mathrm{c}$.

Ministers of Ukraine "On Approval of the National Qualifications Framework”]. (2011). zakon2.rada.gov.ua. Retrieved from: http://zakon2.rada.gov.ua/laws/show/13412011 [in Ukrainian].

9. Raven, D. (2002). Kompetentnost v sovremennom obschestve. Vyyavlenie, razvitie i realizatsiya [Competence in contemporary society. Identification, development and implementation]. Moscow: "Kogito-Tsentr" [in Russian].

10. Slovnyk ukrainskoi movy [Dictionary of the Ukrainian language]. (1978). sum.in.ua. Retrieved from: http://sum.in.ua/p/9/898/1 [in Ukrainian].

11. Solyanikov, Yu. V. (2003). Obespechenie kachestva podgotovki magistrantov pedagogicheskogo universiteta $\mathrm{k}$ nauchno-issledovatelskoy deyatelnosti [Providing the quality of Master degree students preparation for research activities at a pedagogical university]. Extended abstract of candidate's thesis. St. Petersburg [in Russian].

12. Fedina, V. S. (2009). Formuvannia profesiinoi kompetentnosti u maibutnikh fakhivtsiv-skhodoznavtsiv [Formation of professional competence of future specialistsorientalists]. Extended abstract of candidate's thesis. Kyiv [in Ukrainian].

13. Kholodnaya, M. A. (2002). Psikhologiya intellekta. Paradoksy issledovaniya [Intelligence psychology. Study paradoxes.]. St. Petersburg: SPb [in Russian]. 
Наталія Олександрівна Оськіна, кандидат педагогічних наук, доцент кафедри західних і східних мов та методики їх навчання, Південноукраӥнський національний педагогічний університет імені К. Д. Уиинського, вул. Старопортофранківська, 34, м. Одеса, Украӥна

\section{ПРОФЕСІЙНА ПІДГОТОВКА БАКАЛАВРІВ У ГАЛУЗІ СХОДОЗНАВСТВА В ПЕДАГОГІЧНОМУ УНІВЕРСИТЕТІ}

Інтенсивне розширення політичних, економічних і культурних зв'язків України на міжнародній арені, довгостроковий розвиток відносин із орієнтальними народами викликали появу наукового інтересу до країн сходу. Наукові дослідження в цьому напрямі зумовлюють необхідність формування професійної підготовки фахівцівсходознавців: філологів східних мов, політологів, дипломатів із міжнародних відносин, менеджерів зовнішньоекономічної діяльності, сходознавців-культурологів, країнознавців та істориків. Аналіз сучасних досліджень дозволив побачити, що різні психолого-педагогічні та лінгво-методичні аспекти підготовки майбутніх сходознавців або філологів-сходознавців були предметом наукового пошуку. Але специфіка підготовки бакалаврів в галузі сходознавства саме в педагогічному університеті залишилася без уваги, що дає нам можливість актуалізувати дослідження з цієї проблеми. Метою статті було дослідити та визначити поняття «підготовка бакалаврів у галузі сходознавства в педагогічному університеті». Синтезуючи визначення сходознавства як науки, визначення бакалавра як фахівця з певними характеристиками, а також розглядаючи професійну підготовку бакалаврів у галузі сходознавства в педагогічному університеті крізь призму професійно-педагогічної компетентності, ми дійшли висновку, що підготовка бакалаврів у галузі сходознавства в педагогічному університеті - це процес формування професійно-педагогічної компетентності, яка визначає здатність людини успішно вирішувати складні спеціалізовані завдання та практичні проблеми з навчання певної сходознавчої дисципліни, враховуючи різноманітність штучних форм і соціально обумовлених моделей поведінки, творчої діяльності та рівнів розвитку соціумів переважно азіатсько-африканського просторового ареалу, розглядаючи їх соціокультурне побутування в контексті наукової парадигми глобальної взаємодії культур і цивілізації.

Ключові слова: професійна підготовка, сходознавство, сходознавець, бакалавр, професійно-педагогічна компетентність.

\section{Наталия Александровна Оськина, кандидат педагогических наук, доцен кафедры западных и восточных языков и методики их обучения, Южноукраинский национальный педагогический университет имени К. Д. Ушинского, ул. Старопортофранковская, 34, г. Одесса, Украина}

\section{ПРОФЕССИОНАЛЬНАЯ ПОДГОТОВКА БАКАЛАВРОВ В ОБЛАСТИ ВОСТОКОВЕДЕНИЯ В ПЕДАГОГИЧЕСКОМ УНИВЕРСИТЕТЕ}

Интенсивное расширение политических, экономических и культурных связей Украины на международной арене, долгосрочное развитие отношений с ориентальными народами вызвали появление научного интереса к странам востока. Научные исследования в этом направлении обусловливают необходимость формирования профессиональной подготовки специалистов-востоковедов: филологов восточных языков, политологов, дипломатов по международным отношениям, менеджеров внешнеэкономической деятельности, востоковедов-культурологов, страноведов и историков. Анализ современных исследований позволил увидеть, что различные психолого-педагогические и лингвометодические аспекты подготовки будущих востоковедов или филологов-востоковедов были предметом научного поиска. Но специфика подготовки бакалавров в области востоковедения именно в педагогическом университете осталась без внимания, что дает нам возможность актуализировать исследования этой проблемы. Целью статьи было исследовать и определить понятие «подготовка бакалавров в области востоковедения в педагогическом университете». Синтезируя определения востоковедения как науки, определения бакалавра как специалиста с определенными характеристиками, а также рассматривая профессиональную подготовку бакалавров в области востоковедения в педагогическом университете сквозь призму профессионально-педагогической компетентности, мы пришли к выводу, что подготовка бакалавров в области востоковедения в педагогическом университете - это процесс формирования профессионально-педагогической компетентности, которая определяет способность человека успешно решать сложные специализированные задачи и практические проблемы по обучению определенной востоковедческой дисциплины, учитывая разнообразие искусственных форм и социально обусловленных моделей поведения, творческой деятельности и уровней развития социумов преимущественно азиатско-африканского пространственного ареала, рассматривая их социокультурное бытование в контексте научной парадигмы глобального взаимодействия культур и цивилизации.

Ключевые слова: профессиональная подготовка, востоковедение, востоковед, бакалавр, профессиональнопедагогическая компетентность. 